\title{
Empowerment of Balinese Local Wisdom and Important Elements of Community Life as Learning Sources in of IPS SMP/MTs in Buleleng Regency
}

\author{
I Wayan Kertih ${ }^{1, *}$ I Gede Astra Wesnawa ${ }^{1}$ I Putu Sriartha ${ }^{1}$ Tuty Maryati $^{1}$
}

\author{
${ }^{I}$ Master of Social Science Education Study Program, Universitas Pendidikan Ganesha, Singaraja, Indonesia \\ *Corresponding author.Email:wayankertih@gmail.com
}

\begin{abstract}
The study was aimed at identifying and analysing the Balinese local wisdom forms and essential aspects of community life in order to use as a complement to social studies material for SMP/MTs. This study was a library research design. Curriculum materials, books of community wisdom, and important elements of community life are among the study's objects. Data collection techniques were applied interviews, observations, documentation studies, and expert evaluation. The qualitative data was processed by non-statistical. The study's results revealed that there were several types of local wisdom and important element of community life that can be evolved as a supplement of teaching materials in social studies learning.
\end{abstract}

Keywords: Balinese Local Wisdom, Learning Resources, Social Studies Learning for SMP/MTs

\section{INTRODUCTION}

Social studies subjects are educational programs that foster critical thinking abilities, learning capacities, curiosity, and caring and responsible attitudes toward the social environment, as defined by Minister of Education and Culture Regulation No. 58, 2014 controlling the Curriculum of SMP/MTs. The primary purpose of the rule is to ensure that social studies education prepares students to be active citizens. As a result, instructors must strive diligently to improve their classes through the use of school resources and facilities, as well as by empowering key members of the community. Education in social studies must also be connected to indigenous knowledge, environmental awareness, mental, social, moral, and spiritual activities. As a result, it is critical to select and implement a variety of learning aids that will assist children in reaching their full cognitive, social, and emotional potential.

Local wisdom, which can be used as material supplements and learning tools in the classroom, is a crucial component of community life [1-3]. The use of community life is considered as a fun educational activity and material. [4]. It could give concreates experiences. Through social studies learning with local wisdom, these competencies can be the basis for instilling the worth that humans are part of society. This is a good reminder for the social sciences could be a good tools to deliver and shape attitude and soft-skills [5].

In line with the above thought, the development of educational programs and processes in Bali is suspected to be strongly linked to the context and socio-cultural processes of the Balinese people. Empirically, several research results have shown these symptoms [6], [7]. The cultural approach is thought to be firmly held and implemented adaptively and flexibly in current Balinese life, which than can be developed into learning materials [2] [8].

Adhering to the facts, phenomena, and assumptions as described above, and learning from the weaknesses of the implementation of social studies learning as described above, it is very important to do research.

\section{METHOD}

The current research consisted of a systematic search of the literature seeking philosophies, ideas, concepts, and methods in social studies education that make use of local wisdom and important aspects of community life as learning resources. All aspects of social studies learning in SMP/MTs were investigated and implemented as the subject of the study, which included curriculum materials, textbooks, and references to learning models that included dimensions of empowering local wisdom, 
as well as significant elements of community life as a learning resource.

Interviews, observation, paperwork, and expert judgment were all used to acquire the information for this research. Field notes, a camera, and procedures for interviewing and observing were some of the equipment that were employed.

During the course of the investigation, qualitative information was acquired. An analysis approach that was not statistical in nature was used to characterize the study's content, logic, procedure, and outcome (output) as a result of this data processing method [9].

\section{RESULTS AND DISCUSSION}

\subsection{Results}

According to their findings, it was discovered by researchers that there are various different forms of Balinese local knowledge that might be employed as a source of social studies teaching materials for SMP/MTs in Buleleng Regency. This local wisdom can be classified into three forms, namely: (1) Local ideologies and traditions that refer to certain understandings in dealing with life and determining social order. The ideology and traditions of the people; (2) Relationships and social networks which are a form of functioning social ties, be it ties between people in various forms and ties between groups; and (3) local institutions that function for the interests of groups and communities.

The local wisdom of the Balinese people which are included in the form of local ideologies and traditions, including Tri Hita Karana Philosophy, Tri Kaya Parisudha Teachings, Tatwamasi, Karmapala, Rwa Binedha, Segilik-seguluk, Menyama-braya, Meguwakguwakan, Megeret-pandan, Puputan, Pesaja, Meyadnya, De ngaden awak bisa.

The local wisdom of the Balinese people are included in the form of relationships and social networks, including: Paguyuban, Seka-seka, such as: SekaTerunaTeruni, Seka Drama Gong, SekeGenjek, and many other laiseka-seka scattered in Bali, Pasorohan ,Megibung, Subak System, Ngulkul, Sangkep.

The Local wisdom in the form of local institutions, among others: Paibon Temple/Kawitan Temple, Banjar Adat, Pakraman Village, Majelis Alit, Majelis Madya, Majelis Agung, Pecalang, Awing-Awig, Perarem, Pasubayan, Paruman, Ganesha Statue, Republic Temple, Ngayah (gotong royong), Megibung, Subak.

Furthermore, in addition to the aforementioned local wisdom, there are important aspects of community that can be used as learning resources, such as traditional and modern market with adjacent shopping complexes.
Traditional markets can still be found in every district/city, sub-district, and even hamlet on Bali, despite the modernization of the island. It is possible to use traditional marketplaces as social studies study materials in particular situations. For example, likewise, there are places of worship, such as the Pura, which is a Hindu sacred spot where people can pray, in addition to commercial malls and traditional markets. Apart from being a place of worship, temples in Bali have historical importance that makes them ideal for use as social studies learning resources, including PuraBesakih, Uluwatu, Lempuyang, Goalawah, Pulaki, PonjokBatu, PuraJagadNatha which are in every Regency/City in Bali, and many other temples.

Mosques are places of worship for Muslims whose existence is spread all over in Buleleng Regency, subdistricts, to the village/kelurahan level in Bali. Jami Great Mosque is one of the mosques in Singaraja City that are suitable for learning resources. This mosque serves as a place of worship for Muslims in Singaraja and its surrounding areas. The Bugis Village Head Office is located adjacent to the Jami Great Mosque, to the right of the Jami Grand Mosque. The Banjar Bali Community Hall is located about 100 meters south of the Great Mosque of Jami. The Bugis Village Head Office is a kelurahan-level government institution with a Muslim majority. Between meetings, the Banjar Bali Community Hall acts as a gathering place for the residents of Banjar Pakraman, a village in the indigenous Banjar Bali region, the majority of whom are Hindu. It is possible for two groups of people (communities) to coexist despite the fact that the adherents of the two social organizations come from two different religious traditions.

Other places of worship, besides temples and mosques, can be found all across Singaraja and the Buleleng regency, including Viharas and churches, amongst many others. The Vihara in Banjar District is one of the temples that can be used as social studies educational resources, and it is located in the district. The Hot Springs Tourist Attraction is within walking distance of this temple. As an alternative to the Hot Springs in Banjar District, other tourism objects can also be added, such as the waterfall of Gitgit, Lovina Beach, and Air Sanih.

Colonial architecture, which is currently used as government offices, can be found in regencies and cities all around Bali province, including the former Buleleng harbor in Buleleng Regency, which was formerly known as Pabean. Historically, this location was significant since it served as the site of the Sunda Kecil Government Center. As an icon of Buleleng, the Singa Ambara raja Statue, could also be included in the learning materials. Those places would be great places to visit and to learn the history of Buleleng. 


\subsection{Discussion}

In many studies, it has been proven that local wisdom can be used as a powerful and potential socio-cultural capital as support and glue to build the nation's character. Therefore, efforts are needed to excavate, study and utilize as well as preserve the hidden pearls called local geniuses. This effort can be done through education and learning programs in schools, including through social studies learning in SMP/MTs. Through social studies learning with local wisdom, these competencies can be the basis for instilling the value that humans are part of society. In this regard, it is important to study local cultural wisdom.

The importance of empowering local wisdom and important elements of community life in social studies learning is as a strategy to filter positive influences that come from outside to be developed and counteract their negative effects, namely by applying knowledge, values, and social skills in society which have existed in Bali. Therefore, the constancy of Bali can be maintained, including preserving the culture, environment, and social life of Bali. For this reason, social studies education must be an integrative study that can empower all potential learners to have the capability to overcome the problems of human life in various dimensions of space, time, activity, and values in their environment. Social studies education, in accordance with its essence as an integrative study of the social sciences, humanities, religion, and culture, must be able to deliver students to the truth and also the happiness of life. Social studies learning thus has the responsibility of producing good citizens, having strong knowledge, and being able to lead a meaningful life [10].

The relative merits of various educational goals and educational instruments can be traced back to the social, cultural, political, and economic settings in which people learn and educational institutions operate, as well as the goals and educational instruments themselves. Interestingly, this appears to be closely related to the functional structuralism position, which asserts that school education serves to educate the younger generation in order to provide them with a linguistic system, as well as the knowledge, values, attitudes, and abilities necessary to perform their roles in society, including those of the family. During critical reconstruction, members of the school community (principals, teachers, and students) work collaboratively to re-create the image of a more democratic modern society that is more balanced in terms of ensuring the social, political, cultural, and economic rights to life of the community's local Balinese people interests, as well as national interests and global community interests [6].

Improving the community's ability to serve as a learning resource is an important first step. The reason for this is that schools are not the only places where students can learn to develop life skills, and formal education is not the only place where students can learn to develop life skills. It is possible to use the community and the workplace as a vehicle for education and learning in order to develop the necessary life skills in a social setting. Acquiring knowledge by incorporating major aspects of everyday life in society will be more relevant because it is not just formal science that has been validated, but also learning significant components of daily life in society. The notion of participatory learning, which is based on the concept of learning by doing in order to develop relevant life skills necessary for reintegration into society, can also be applied in the workplace to foster meaningful learning opportunities [1] [4].

During real social life in the environment that surrounds a school, students can directly build and develop social, cultural, and religious values. They can also develop social skills that will be useful to them in the lives of their communities, nations, and states after they have graduated from high school. This is referred to as a school education that is based on real-world experience. Consequently, on a local, national, and international scale, schools are required to accept, adapt, and develop interests that will guide and direct the values and behaviors of all school members and the wider community [2], [10], [11].

Social studies are being integrated. The involvement of environmental activities, mental, social, and moral activities arising from communal life, as well as spiritual activities, are also essential. The selection and provision of a variety of learning tools and learning media is therefore crucial in facilitating a learning process that can awaken students' full potential, including their intellectual, social and emotional potential. In order to achieve this aim, students need to have outdoor activites to observe the surroundings, to explore the heritage and the life of the community. The heritage is a ready-used materials for the students to learn history. In Indonesia, local wisdom on a variety of important areas of people's lives can be used as supplemental materials and learning methods to supplement formal educational materials. [13]. A pleasant educational strategy for enhancing a variety of learning aids is to draw on major components of community life as a source of information and learning opportunities [4].

\section{CONCLUSION}

\subsection{Conclusion}

Accordingly, it's possible to conclude that the near vicinity of schools has significant resources for social studies education, including local expertise and crucial community characteristics. The many types of local 
institutions that the Balinese people have developed over time are capable of adapting to the diverse ecological, social, political, and economic issues that they are confronted with today. To provide real-world learning opportunities for children, the school community must navigate the full social, political, cultural, and economic framework in which it operates. This is a journey that the school community embarks on every day.

\subsection{Suggestions/Recommendation}

It is impossible to isolate the influence of the community's socio-cultural context on social studies education. In addition to leveraging the facilities and learning resources available in schools, teachers are expected to empower local wisdom and important components of community life in the school's immediate neighborhood as part of the development of their learning materials.

\section{REFERENCES}

[1] J. Jarolimek and Foster, Social Studies in Elementary Education. New York-London: Macmillan Publishing Company and Collier Macmillan Publishers, 1989.

[2] G. M. Schuncke, Elementary Social Studies; Knowing, Doing, Caring. USA: MacMillan Pub.Co, 1988.

[3] W. Kertih, Pengembangan Model Keterampilan Proses Berbasis Kompetensi di Sekolah Dasar. Penelitian Fundamental, 2007.

[4] R. W.B and J. D. Mc. Aulay, Social Studies for Today's Children. Meredith Pub, USA: Appleton-Century-Croft, 1964.

[5] Subagia, "Balinese Indigenous Worldview and Its Role in The Reforms of Science Education in Bali," Majalah Ilmiah Aneka Widya, vol. XXXIII, no. 3, pp. 71-81, 2000.

[6] Sukadi, Pendidikan IPS sebagai Rekonstruksi Pengalaman Budaya berbasis Ideologi Tri Hita Karana pada SMU Negeri 1 Ubud Gianyar Bali. Bandung: Sekolah Pascasarjana UPI, 2006.

[7] I. P. Sriartha and I. W. Kertih, "Subak Local Wisdom as Social Studies Learning Source in Junior High School," in Proceedings of the 4th Asian Education Symposium (AES 2019), 2020, pp. 23-27, doi: https://doi.org/10.2991/assehr.k.200513.006.

[8] N. G. A. M. Sri Evariani, I. W. Kertih, and I. Akhmad Haris, "Pengaruh Penerapan Model Pembelajaran Sains Teknologi Masyarakat (STM) Terhadap Keterampilan Berpikir Kritis dan Prestasi Belajar IPS di SMP Negeri 1 Penebel," J. Pendidik. IPS Indones., vol. 1, no. 1, pp. 38-46, 2017, doi: 10.23887/pips.v1i1.2823.

[9] S. Nasution, Metode Penelitian Naturalistik Kualitatif. Bandung: Tarsito, 1984.

[10] N. Sumantri, Pembaharuan Pendidikan IPS. Bandung: Rosda Karya, 2001.

[11] N. Supratna and P.Waterworth, "Tantangan dalam Kurikulum IPS," Mimb. Pendidikan, J. Pendidik., no. 2 Tahun XVI, pp. 31-37, 1997, [Online]. 